The association between upper limb function and variables at the different domains of the International Classification of Functioning, Disability and Health in women after breast cancer surgery: a systematic review

De Groef Ana, , Van der Gucht Elien ${ }^{\mathrm{a}}$, Dams Lore ${ }^{\mathrm{b}}$, Evenepoel Margaux ${ }^{\mathrm{a}}$, Teppers Lien, ${ }^{\mathrm{c}}$ Toppet - Hoegars Julie, ${ }^{\mathrm{c}}$ De Baets Liesbet*c

${ }^{a}$ KU Leuven - University of Leuven, Department of Rehabilitation Sciences, Leuven, Belgium

${ }^{b}$ University of Antwerp, Department of Rehabilitation Sciences and Physiotherapy, MOVANT, Antwerp, Belgium

${ }^{c}$ Hasselt University, Faculty of Rehabilitation Science, Diepenbeek, Belgium

Correspondence details here including e-mail for the corresponding author:

Liesbet De Baets (ORCID 0000-0002-1370-2090)

Agoralaan Building A

3590 Diepenbeek

Belgium

Liesbet.debaets@uhasselt.be

Social media handles: 
@LiesbetDebaets

@AnDeGroef

@ElienVdG

@DamsLore

ORCIDs:

An De Groef: 0000-0001-6771-2836

Elien Van der Gucht: 0000-0002-9778-1143 


\section{The association between upper limb function and variables at the different domains of the International Classification of Functioning, Disability and Health in women after breast cancer surgery: a systematic review}

Purpose: To investigate the variables per International Classification of Functioning, Disability and Health (ICF)-domain that are associated with upper limb (UL) function in women after breast cancer surgery.

Materials and Methods: PubMed and Web of Science were searched until 7 January 2020. Eligibility criteria were: prospective investigation of an association between one or more variables of the ICF model and UL function in women after breast cancer surgery. PRISMA guidelines were used to conduct and report the systematic review. The Quality In Prognosis Studies tool (QUIPS) was used to evaluate risk of bias.

Results: Twelve studies were included (2244 participants). Risk of bias of the included studies was low to moderate. Variables at the ICF-function level that were systematically associated with decreased UL function across multiple included papers were: increased UL pain, decreased shoulder range of motion, decreased handgrip strength and a higher number of comorbidities. Results on the association between UL function and variables at other ICF-domains were conflicting.

Conclusion: UL function was associated with certain variables at the ICFfunction level. Variability in disease stages, treatment and measurement methods might explain inconsistent associations with other variables. Only limited studies investigated associations between UL function and psychosocial factors. 
Keywords: breast cancer; dysfunction; association; upper extremity; upper limb

\section{Introduction}

Breast cancer $(\mathrm{BC})$ is the most common type of cancer diagnosed in women. More specifically, it covers more than $33 \%$ of all cancers in women worldwide [1]. The different treatment modalities for BC, including axillary and breast surgery, radiotherapy, chemotherapy, hormone therapy and immunotherapy, can have a wide range of somatic sequelae at the breast, the shoulder region and/or the entire upper limb (UL). Commonly reported morbidities are arm lymphedema [2], UL numbness [3, 4] and axillary web syndrome (cording) [5], with reported prevalences of $20 \%$, up to $78 \%$ and up to $86 \%$, respectively [5, 6, 7]. Furthermore, shoulder range of motion (ROM) deficits are frequently described after BC surgery and radiotherapy, with reported prevalence rates from $0 \%$ to $84 \%$, depending on the axillary surgical management $[3,4,8,9]$. Apart from reduced mobility, also UL muscle weakness is seen in women following BC surgery (prevalence from $20 \%$ to $50 \%$ ) $[4,10,11]$. At last, (persistent) UL pain is prevalent after $\mathrm{BC}$ treatment $[12,13,14,15,16]$, with reported prevalences ranging from $27 \%$ to $79 \%$ after finishing primary treatments.

The awareness on the presence of the impairements in BC survivors as described above has increased over the past decades. However, the impact of these impairments may be of larger concern than the impairments themselves, as they may lead to disabilities on all different domains of a person's functioning [17]. As described by the International Classification of Functioning, Disability and Health, these domains consist of body 
functions, activities (functioning at level of the individual) and participation (functioning as a member of society), as well as interactions with environmental and personal (including psychological) factors [17].

Decreased UL function, i.e. experiencing difficulties in performing activities of daily living with the UL, is indeed very common following breast cancer treatment, with a prevalence rate of $60 \%$ at one year after surgery $[4,18,19]$. A decreased UL function has a negative influence on the quality of life, the ability to particpate in society and the perceived wellbeing of BC survivors [20, 21]. Therefore, re-acquiring optimal UL function is one of the primordial goals of post-surgical physical therapy.

Currently applied rehabilitation programmes in women following BC surgery show rather disappointing results regarding the restoration of UL function $[22,23]$. To improve future management programmes, it is therefore important to have knowledge on the factors underlying the development and chronification of UL dysfunction in women following $\mathrm{BC}$ treatment.

First, as described above, different functional impairments at the level of the body are potential contributors to a decreased UL function after BC surgery. However, factors on other ICF domains should be considered as well, including activity - and participation related factors and other personal and external factors. Research in non-cancer populations for example, identified self-efficacy and expectations of recovery, together with being unemployed, as predictors of UL function [24].

To our knowledge, a comprehensive overview of the currently known variables associated with UL function after BC surgery is not available. Therefore, this review aims to systematically describe the available knowledge on the factors (classified per domain of the ICF) related to UL function in women following BC surgery. 


\section{Methods}

This review was designed according to the PRISMA criteria for systematic reviews [25] and protocol details were registered in the international prospective register of systematic reviews (PROSPERO, ID 137042, definitive registration number not received yet).

A literature search was conducted using the electronic databases 'PubMed' and 'Web of Science' until January, $7^{\text {th }}, 2020$, using a combination of search terms for 'breast cancer', 'upper limb' and 'dysfunction' (Supplemental online material 1).

Studies were eligible if (1) the relation between a variable located at one of the domains of the ICF model (including function-related variables, personal variables, external variables, and treatment-related variables) and UL function in women after breast cancer surgery was assessed, (2) the statistical method used was regression analysis with perceived UL function as dependent variable, (3) the manuscript was peer-reviewed, available in full text, and written in English. Reasons for exclusion were: (1) previous treatment(s) for cancer(s) in the upper extremity, (2) studies concerning men, (3) retrospective studies, case studies, and/or (systematic) reviews, (4) studies using a selfconstructed questionnaire to measure UL function as outcome, and (5) studies without ethical approval and informed consent. If eligible criteria were not clear, authors were contacted directly, with up to three attempts before exclusion.

The study selection was performed in two phases. After removing duplicates, two researchers ( $\mathrm{xx}$ and $\mathrm{xx})$ first independently screened the titles and abstracts for inclusion. Afterwards, full texts of these papers and from those which the title and abstract did not provide enough information, were read by the same reviewers for the final paper selection. If both reviewers disagreed regarding eligibility, the article was discussed with a third reviewer $(\mathrm{xx})$ to achieve consensus. Furthermore, the reference lists were screened for relevant papers that were missed based on the systematic database search. 
The risk of bias (RoB) of each included study was assessed by two researchers independently (xx and xx) using the Quality In Prognosis Studies (QUIPS) tool [26, 27]. Although specifically developed to study risk of bias in prognostic research, the tool was also used when cross-sectional correlational studies were selected for inclusion, given that most items are relevant for those studies as well. The QUIPS tool uses six important domains that should be critically appraised when evaluating validity and bias in studies of prognostic factors: 1) study participation, 2) study attrition, 3) prognostic factor measurement, 4) outcome measurement, 5) study confounding, 6) statistical analysis and reporting. Based on the ratings of the included items, a conclusive judgment of the RoB within each domain is made and expressed on a three-grade scale (high, moderate or low RoB).

The overall RoB rating was determined based on the mean scores of the six domains per study, with score 2 for high, 1 for moderate and 0 for low RoB. Mean scores from 0 to 0.65 , from 0.66 to 1.32 and from 1.33 to 2 were considered low, moderate and high RoB respectively. The Quality In Prognosis Studies tool is recommended to assess RoB by the Cochrane Prognosis Methods Group for prognosis studies [28].

Data extraction from the included studies was performed by one researcher ( $\mathrm{xx}$ ) and cross-checked by another researcher $(\mathrm{xx})$. The authors retained the study population and number of participants, participant characteristics including stage and treatments, research setting, time after surgery, the dependent (i.e. measure of UL function) and independent variables (i.e. variables at different domains of the ICF, see further) from the regression analyses, and the results including a measure of association and level of significance. Results of multivariable regression analyses were extracted; variables that were not significant in the multivariable model were not reported (Table 1). 
The independent variables that could possibly be associated to UL function were categorized into four domains based on the ICF (World Health Organization, 2013).

No meta-analysis could be performed due to study-heterogeneity in investigated independent variables. Therefore, a best-evidence synthesis was performed.

\section{Results}

The conducted database search resulted in 3495 articles. Seven articles were additionally screened based on expert opinion and by checking the reference lists of the selected papers. The full texts of 27 papers were read and the corresponding author of one manuscript was contacted for more information. Eventually, 12 papers were retained for inclusion in this systematic review based on the eligibility criteria. The paper selection process is visualized in figure 1.

[Insert figure 1 here]

Eleven papers had a cross-sectional design with a mean time after surgery of less than 1 year [29, 30], between 1 and 2 years after surgery $[19,31,32,33]$ or more than 2 years after surgery [34, 35, 36, 37]. One study did not report time after surgery [38]. One study followed a cohort of women longitudinally from 6 to 18 months post-operatively [39].

In all but one study, the (Quick)DASH was used as patient reported outcome measure of UL function. In one study [33], the Pennsylvania Shoulder Score was administered next to the DASH. One study used the SPADI as dependent outcome [35].

No consistent set of independent variables was evaluated across the different studies. The association between UL function and factors at function level of the ICF $(\mathrm{n}=3)[33,34,38]$; between UL function and a combination of function and personal factors $(\mathrm{n}=1)$ [37]; between UL function and a combination of function and treatment 
factors $(\mathrm{n}=1)$ [31]; between UL function and a combination of personal and treatment factors $(n=2)[32,35]$; between UL function and a combination of function, personal and treatment factors $(\mathrm{n}=2)[19,36]$; between UL function and a combination of personal, external and treatment factors $(n=1)$ [29]; between UL function and a combination of personal, function, external and treatment factors $(n=2)[30,39]$ was studied in the included papers. As such, function factors were assessed in 9 studies, treatment factors in 8 studies, personal factors in 6 studies and external factors in 3 studies.

Results of the factors significantly associated with UL function are described per study in table 1 . In table 2, a summary of the different assessed independent variables with and without association with UL function is presented, per ICF category.

[insert table 1 and 2 here]

Significant predictors of UL function that were consistent across multiple studies and not contradicted by other included studies, were all factors on function level: UL pain quality as assessed by the McGill pain questionnaire [19, 34], shoulder abduction ROM [19, 36, 37], number of comorbidities [34, 37] and hand(grip) strength $[19,37]$.

Signs and symptoms of central sensitization [19] and UL numbness [31] (function level), post-operative infection [29] (treatment level) and pain catastrophizing [19] (external level) were also identified predictors of UL function. However, their predictive value was only shown in one study, although not contradicted in other studies. Additionally, Hayes et al found that presence of more than one physical symptom was associated with decreased UL function [39] (function level).

The results on the influencing role of function factors "UL pain intensity" $[19,31$, 36, 38], "lymphedema"[30, 31, 34, 36, 37, 39] and "shoulder girdle/upper extremity strength" $[33,37,38]$; the treatment factors "type of adjuvant therapy" $[19,29,30,32,35$, 
$36,39]$ and "time since surgery" $[29,31,35]$; and the personal factors "BMI"'[19, 29, 30, 32, 39] and "income" [30, 32, 37, 39] on UL function were contradictory between different studies.

The factors not significantly associated with UL function, as found by multiple studies, were: "shoulder flexion and rotation $\operatorname{ROM"~}[19,36,37]$ on function level; "affected side" [19, 30, 35, 39], "type of surgery" [19, 29, 30, 35, 36, 39] and "disease stage" [29, 30, 35, 36] on treatment level; "age" [19, 30, 32, 35, 36, 37, 39], "race/ethnicity" [35, 37], "occupation" $[30,36,37]$ and "education level" $[29,30]$ on personal level; and "childcare responsibilities" [30, 39] and "partner status" [29, 30, 32, 39] on external level.

The factors not significantly associated with UL function, as found in only one study, were: "passive shoulder ROM" [33], "menopausal status" [37], "fine motor skills" [37], "tactile sensitivity" [37], "vibration perception threshold" [37] and "local pressure hypersensitivity" [19] on function level; "treatment-related complications" [39] and "reconstructive surgery" [32] on treatment level; "health literacy" [32], "pain vigilance and awareness" [19], "performance and activity status" [37], "diabetes mellitus" [32], "prior shoulder complaints" [32] and "physical activity level" [39] on personal level; and "insurance rate" [30] on external level.

In table 3, the QUIPS RoB results are shown. Five studies had a low RoB whilst seven a moderate RoB. Mainly on the item "3. Prognostic factor measurement", risk factors were identified in the studies with a moderate overall RoB.

[insert table 3 here]

\section{Discussion}


The aim of this review was to get an overview of the variables per domain of the ICF model associated with UL function in women after breast cancer surgery. The variables that were systematically associated with decreased UL function across multiple included papers were increased UL pain, decreased shoulder ROM, decreased handgrip strength and a higher number of comorbidities; all at function level of the ICF. Treatment-related, personal and external factors appeared to have less influence on UL function. However, external factors were generally understudied.

UL pain intensity and quality $[19,31,34,38]$ were the first factors identified by multiple studies and contradicted only by one study [36]. Together with fatigue, pain is one of the most prevalent and persistent problems reported by breast cancer survivors [16]. Several studies have confirmed the impact of pain on a person's functioning after breast cancer. This review highlights the impact on UL function in particular. Pain may impair UL function in different ways. Motor function of UL muscles may be inhibited by pain $[40,41,42]$ and/or pain may influence a person's behavior and result in pain-related fear and avoidance of certain activities [43]. Moreover, one might try to get control over pain and catastrophize about the experienced pain. This is supported by the results of this review since pain catastrophizing was associated with decreased UL in one study [19], which took a high number of potential contributors to UL function into account. However, pain is a complex phenomenon and other dimensions besides pain intensity and pain quality should be investigated as contributors to UL function, such as the dominant pain type. Symptoms of central sensitization as assessed by the Central Sensitisation Inventory were in one study associated with UL function [19]. Second, in particular abduction shoulder ROM was identified as associated factor, while forward flexion and rotation ROM were not. Possibly, hypertonic pectoral muscles and soft tissue restrictions in the pectoral region, often seen after surgery and/or radiotherapy for breast cancer, explain the 
impaired abduction movement [22, 44, 45]. Decreased soft-tissue flexibility at the pectoral region is indeed described in literature $[44,46]$. Third, our results confirm that handgrip strength is an important measure of function in $\mathrm{BC}$ patients as already indicated by Cantarereo-Villanueva et al [47]. For other factors at the different domains of the ICF model, evidence is inconsistent.

No less than 8 out of 12 studies investigated the association between treatmentrelated factors and UL function. Remarkably, no clear associations were identified between applied medical treatments and the subsequent UL function. Clear associations may not have been detected due to complexity and heterogeneity of the (combinations of) treatment modalities for breast cancer. With breast cancer treatment becoming more personalized, different treatment modalities are combined depending on the stage and type of cancer. In particular for the topic of this review, different surgical approaches and radiotherapy modalities may affect UL function in different ways. Patient and treatment characteristics of the included studies are indeed highly variable and heterogeneous (table 1). Assis et al was e.g. the only study including women with bilateral surgery [31] and two studies did not exclude women with a history of shoulder pathologies [31, 32]. Another explanation may be the variable time after surgery the included studies took place. Time after surgery ranged from 6 months up to 6 years after surgery. Questions may raise to which extent treatment-related variables are relevant and attributable to UL function at these time points post-surgery.

Next to the discussion of the specific study-results, some general issues related to this type of research in this specific population should be addressed. First, the breast cancer population becomes more heterogeneous given the wide range of treatment 
options and consequent side effects, possibly affecting a person's functioning. To increase the power/value of studies investigating associations with UL function, it is important to adequately recruit the specific population of interest. Second, it is important to acknowledge that the result of a regression analysis is dependent on the number and type of different independent factors included in the model. This is illustrated in the present review by the fact that the few significant associations for treatment-related factors were found by those studies not including independent factors at function level. This raises the question how many and which combination of independent factors should be considered in these studies, taking into account sufficient statistical power for proper regression analyses. In this review, no less than 41 independent factors were investigated. Future research should consider available results and select the most relevant factors reflecting all domains of a person's functioning on the ICF model. Third, all studies, except one[39] had a cross-sectional design. Indepth understanding of determinants of UL function in BC patients requires more robust longitudinal studies with a baseline (i.e. at time of diagnosis) assessment and sufficient follow-up assessments. Most included cross-sectional studies took place more than one year after breast cancer surgery. Again, relevance of certain cancer- and treatment-related factors at this stage should be questioned. Other factors at other domains of the ICF model, e.g. personal psychological factors and environmental/social factors such as work and family status, may be more interesting to investigate at this stage. Additionally, no study identified potential mediators and moderators of the relation between certain variables and UL function at different time points after surgery, which certainly is a limitation.

Apart from potential methodological limitations in the included studies, there might also have been a limitation to the search used for this systematic review. Although 
a systematic search was performed in multiple databases and experts were contacted, it is possible that relevant studies were not included in this review.

\section{Clinical implications}

The identified associated factors, i.e. UL pain, decreased handgrip strength and shoulder (abduction) ROM are modifiable factors. This means that the assessment of these factors is essential in the clinical examination of women following breast cancer surgery, and that adequate physical therapy modalities, adapted according to the impairment identified in the clinical examination, are warranted. Such treatments might include specific exercises and mobilizations, which target from the early phase after breast cancer surgery the different identified impairments. This way, impairments and consequent decreased UL function might be prevented or appropriately treated [22, 23, 48].

\section{Future research}

Research in non-cancer populations highlights the importance of psychosocial predictors for (chronic) pain and disability [24, 49]. This review indicates that in (breast) cancer populations, these associations between personal (psychological) and external factors and UL function are not yet properly investigated. Given the complex context of cancer diagnosis and treatment, evaluation of all domains of the ICF model is even more important in this population. Next to negative psychological predictors such as anxiety, depression, stress and avoidance behavior, possible positive traits including optimism, resilience, self-efficacy and positive expectations should be considered. Longitudinal study designs exploring predictors, moderators and mediators are warranted.

\section{Conclusion}


Factors significantly associated with UL function, reported by multiple studies and not contradicted by others are: UL pain, active (abduction) shoulder ROM, handgrip strength and number of comorbidities, all at function level of the ICF model. Given that UL dysfunctions are one of the main sequelae after breast cancer treatment, it is meaningful to get a better understanding of the factors contributing to UL function in order to improve prevention and treatment strategies. 
Acknowledgements: Support statement: ADG is a post-doctoral research fellow of the FWO-

Flanders.

Declaration of interest: The authors report no conflicts of interest

References:

1. Ferlay J, Colombet M, Soerjomataram I, et al. Cancer incidence and mortality patterns in Europe: Estimates for 40 countries and 25 major cancers in 2018. European journal of cancer (Oxford, England : 1990). 2018 Nov;103:356-387. doi: 10.1016/j.ejca.2018.07.005. PubMed PMID: 30100160; eng.

2. DiSipio T, Rye S, Newman B, et al. Incidence of unilateral arm lymphoedema after breast cancer: a systematic review and meta-analysis. The lancet oncology. 2013 May;14(6):500-15. doi: 10.1016/s1470-2045(13)70076-7. PubMed PMID: 23540561; eng.

3. Devoogdt N, Van Kampen M, Christiaens MR, et al. Short- and long-term recovery of upper limb function after axillary lymph node dissection. European journal of cancer care. 2011 Jan;20(1):77-86. doi: 10.1111/j.1365-2354.2009.01141.x. PubMed PMID: 19708945.

4. Hidding JT, Beurskens $\mathrm{CH}$, van der Wees PJ, et al. Treatment related impairments in arm and shoulder in patients with breast cancer: a systematic review. PloS one. 2014;9(5):e96748. doi: 10.1371/journal.pone.0096748. PubMed PMID: 24816774; PubMed Central PMCID: PMCPmc4016041. eng.

5. Koehler LA, Haddad TC, Hunter DW, et al. Axillary web syndrome following breast cancer surgery: symptoms, complications, and management strategies. Breast cancer (Dove Medical Press). 2019;11:13-19. doi: 10.2147/bctt.S146635. PubMed PMID: 30588087; PubMed Central PMCID: PMCPMC6304256. eng. 
6. Leidenius M, Leppanen E, Krogerus L, et al. Motion restriction and axillary web syndrome after sentinel node biopsy and axillary clearance in breast cancer. American journal of surgery. 2003 Feb;185(2):127-30. PubMed PMID: 12559441.

7. Bergmann A, Mendes VV, de Almeida Dias R, et al. Incidence and risk factors for axillary web syndrome after breast cancer surgery. Breast cancer research and treatment. 2012 Feb;131(3):987-92. doi: 10.1007/s10549-011-1805-7. PubMed PMID: 21987036; eng.

8. Verbelen H, Gebruers N, Eeckhout FM, et al. Shoulder and arm morbidity in sentinel node-negative breast cancer patients: a systematic review. Breast cancer research and treatment. 2014 Feb;144(1):21-31. doi: 10.1007/s10549-014-2846-5. PubMed PMID: 24496928; Eng.

9. Gosselink R, Rouffaer L, Vanhelden P, et al. Recovery of upper limb function after axillary dissection. Journal of surgical oncology. 2003 Aug;83(4):204-11. doi: 10.1002/jso.10271. PubMed PMID: 12884231.

10. Rietman JS, Dijkstra PU, Debreczeni R, et al. Impairments, disabilities and health related quality of life after treatment for breast cancer: a follow-up study 2.7 years after surgery. Disability and rehabilitation. 2004 Jan 21;26(2):78-84. doi:

10.1080/09638280310001629642. PubMed PMID: 14668143.

11. Rietman JS, Dijkstra PU, Geertzen JH, et al. Short-term morbidity of the upper limb after sentinel lymph node biopsy or axillary lymph node dissection for Stage I or II breast carcinoma. Cancer. 2003 Aug 15;98(4):690-6. doi: 10.1002/cncr.11545. PubMed PMID: 12910511.

12. Hidding JT, Beurskens CHG, van der Wees PJ, et al. Treatment Related Impairments in Arm and Shoulder in Patients with Breast Cancer: A Systematic Review. PLOS ONE. 2014;9(5):e96748. doi: 10.1371/journal.pone.0096748.

13. Rietman JS, Dijkstra PU, Hoekstra HJ, et al. Late morbidity after treatment of breast cancer in relation to daily activities and quality of life: a systematic review. European 
Journal of Surgical Oncology (EJSO). 2003 2003/04/01/;29(3):229-238. doi: https://doi.org/10.1053/ejso.2002.1403.

14. Swenson KK, Nissen MJ, Ceronsky C, et al. Comparison of side effects between sentinel lymph node and axillary lymph node dissection for breast cancer. Annals of surgical oncology. 2002 Oct;9(8):745-53. PubMed PMID: 12374657; eng.

15. Wang L, Guyatt GH, Kennedy SA, et al. Predictors of persistent pain after breast cancer surgery: a systematic review and meta-analysis of observational studies. Canadian Medical Association Journal. 2016;188(14):E352. doi: 10.1503/cmaj.151276.

16. Harrington CB, Hansen JA, Moskowitz M, et al. It's Not over When it's Over: LongTerm Symptoms in Cancer Survivors-A Systematic Review. The International Journal of Psychiatry in Medicine. 2010 2010/06/01;40(2):163-181. doi: 10.2190/PM.40.2.c.

17. Yang EJ, Kim BR, Shin HI, et al. Use of the international classification of functioning, disability and health as a functional assessment tool for breast cancer survivors. Journal of breast cancer. 2012 Mar;15(1):43-50. doi: 10.4048/jbc.2012.15.1.43. PubMed PMID: 22493627; PubMed Central PMCID: PMCPMC3318173. eng.

18. Rietman JS, Geertzen JH, Hoekstra HJ, et al. Long term treatment related upper limb morbidity and quality of life after sentinel lymph node biopsy for stage I or II breast cancer. European journal of surgical oncology : the journal of the European Society of Surgical Oncology and the British Association of Surgical Oncology. 2006 Mar;32(2):148-52. doi: 10.1016/j.ejso.2005.11.008. PubMed PMID: 16387467; eng.

19. De Groef A, Meeus M, De Vrieze T, et al. Pain characteristics as important contributing factors to upper limb dysfunctions in breast cancer survivors at long term. Musculoskeletal science \& practice. 2017 Mar 14;29:52-59. doi: 10.1016/j.msksp.2017.03.005. PubMed PMID: 28319882.

20. Hack T, Boquiren V, Thomas R, et al. Exploring the relationships between arm morbidity, perceived disability and mood disturbance in breast cancer survivors. Psycho-oncology. 2014;23:204-205. doi: 10.1111/j.1099-1611.2014.3695. 
21. Nesvold IL, Foss SD, Holm I, et al. Arm/shoulder problems in breast cancer survivors are associated with reduced health and poorer physical quality of life. Acta oncologica. 2010;49(3):347-353. doi: 10.3109/02841860903302905.

22. De Groef A, Van Kampen M, Dieltjens E, et al. Effectiveness of postoperative physical therapy for upper-limb impairments after breast cancer treatment: a systematic review. Archives of physical medicine and rehabilitation. 2015 Jun;96(6):1140-53. doi: 10.1016/j.apmr.2015.01.006. PubMed PMID: 25595999.

23. McNeely ML, Campbell K, Ospina M, et al. Exercise interventions for upper-limb dysfunction due to breast cancer treatment. Cochrane database of systematic reviews (Online). 2010 (6):CD005211. doi: 10.1002/14651858.CD005211.pub2. PubMed PMID: 20556760; eng.

24. De Baets L, Matheve T, Meeus M, et al. The influence of cognitions, emotions and behavioral factors on treatment outcomes in musculoskeletal shoulder pain: a systematic review. Clinical rehabilitation. 2019:0269215519831056. doi: 10.1177/0269215519831056.

25. Liberati A, Altman DG, Tetzlaff J, et al. The PRISMA Statement for Reporting Systematic Reviews and Meta-Analyses of Studies That Evaluate Health Care Interventions: Explanation and Elaboration. PLOS Medicine. 2009;6(7):e1000100. doi: 10.1371/journal.pmed.1000100.

26. Hayden JA, Cote P, Bombardier C. Evaluation of the quality of prognosis studies in systematic reviews. Ann Intern Med. 2006 Mar 21;144(6):427-37. doi: 10.7326/00034819-144-6-200603210-00010. PubMed PMID: 16549855; eng.

27. Grooten WJA, Tseli E, Äng BO, et al. Elaborating on the assessment of the risk of bias in prognostic studies in pain rehabilitation using QUIPS — aspects of interrater agreement. Diagnostic and Prognostic Research. 2019 2019/03/07;3(1):5. doi: 10.1186/s41512-019-0050-0.

28. Hayden J, van Der Windt D, Cartwright J, et al. Assessing Bias in Studies of Prognostic Factors. Ann. Intern. Med.2013. p. 280-286. 
29. Hack TF, Kwan WB, Thomas-Maclean RL, et al. Predictors of arm morbidity following breast cancer surgery. Psycho-oncology. 2010;19(11):1205-1212 8p. doi:

10.1002/pon.1685. PubMed PMID: 104935921. Language: English. Entry Date: 20110218. Revision Date: 20150711. Publication Type: Journal Article.

30. Hayes S, Battistutta D, Newman B. Objective and subjective upper body function six months following diagnosis of breast cancer. Breast cancer research and treatment. 2005 Nov;94(1):1-10. doi: 10.1007/s10549-005-5991-z. PubMed PMID: 16172793; eng.

31. Assis MR, Marx AG, Magna LA, et al. Late morbidity in upper limb function and quality of life in women after breast cancer surgery. Brazilian journal of physical therapy. 2013 May-Jun;17(3):236-43. PubMed PMID: 23966141; eng.

32. Chrischilles EA, Riley D, Letuchy E, et al. Upper extremity disability and quality of life after breast cancer treatment in the Greater Plains Collaborative clinical research network. Breast cancer research and treatment. 2019 Jun;175(3):675-689. doi: 10.1007/s10549-019-05184-1. PubMed PMID: 30852760; PubMed Central PMCID: PMCPMC6534523. eng.

33. Harrington S, Padua D, Battaglini C, et al. Upper extremity strength and range of motion and their relationship to function in breast cancer survivors. Physiotherapy theory and practice. 2013 Oct;29(7):513-20. doi: 10.3109/09593985.2012.757683. PubMed PMID: 23343035; Eng.

34. Dawes DJ, Meterissian S, Goldberg M, et al. Impact of lymphoedema on arm function and health-related quality of life in women following breast cancer surgery. Journal of Rehabilitation Medicine. 2008 Aug;40(8):651-8. doi: https://dx.doi.org/10.2340/16501977-0232. PubMed PMID: 19020699; English.

35. Kramer N, Ramjith J, Shamley D. Prevalence of shoulder morbidity after treatment for breast Cancer in South Africa. Supportive care in cancer : official journal of the Multinational Association of Supportive Care in Cancer. 2019 Jul;27(7):2591-2598. doi: 10.1007/s00520-018-4540-3. PubMed PMID: 30456720; eng. 
36. Marazzi F, Masiello V, Marchesano D, et al. Shoulder girdle impairment in breast cancer survivors: the role of range of motion as predictive factor for dose distribution and clinical outcome. Tumori. 2019 Aug;105(4):319-330. doi: 10.1177/0300891619839287. PubMed PMID: 30935295; eng.

37. Smoot B, Wong J, Cooper B, et al. Upper extremity impairments in women with or without lymphedema following breast cancer treatment. Journal of cancer survivorship : research and practice. 2010 Jun;4(2):167-78. doi: 10.1007/s11764-010-0118-x. PubMed PMID: 20373044; PubMed Central PMCID: PMC2882040.

38. de Souza Cunha N, Zomkowski K, Fernandes BL, et al. Physical symptoms and components of labor tasks associated with upper limb disability among working breast cancer survivors. Breast cancer. 2020 Jan;27(1):140-146. doi: 10.1007/s12282-01901004-y. PubMed PMID: 31456165; eng.

39. Hayes SC, Janda M, Cornish B, et al. Lymphedema after breast cancer: incidence, risk factors, and effect on upper body function [Research Support, Non-U.S. Gov't]. Journal of Clinical Oncology. 2008 Jul 20;26(21):3536-42. doi:

https://dx.doi.org/10.1200/JCO.2007.14.4899. PubMed PMID: 18640935; English.

40. Crosbie J, Kilbreath SL, Dylke E, et al. Effects of mastectomy on shoulder and spinal kinematics during bilateral upper-limb movement. Physical therapy. 2010 May;90(5):679-92. doi: 10.2522/ptj.20090104. PubMed PMID: 20223945; eng.

41. Shamley D, Srinaganathan R, Oskrochi R, et al. Three-dimensional scapulothoracic motion following treatment for breast cancer. Breast cancer research and treatment. 2009 Nov;118(2):315-22. doi: 10.1007/s10549-008-0240-x. PubMed PMID: 18998205.

42. Shamley DR, Srinanaganathan R, Weatherall R, et al. Changes in shoulder muscle size and activity following treatment for breast cancer. Breast cancer research and treatment. 2007 Nov;106(1):19-27. doi: 10.1007/s10549-006-9466-7. PubMed PMID: 17221154.

43. Van der Gucht E, Dams L, Meeus M, et al. Kinesiophobia contributes to pain-related disability in breast cancer survivors: a cross-sectional study. Supportive care in cancer : 
official journal of the Multinational Association of Supportive Care in Cancer. 2020 Jan 17. doi: 10.1007/s00520-020-05304-4. PubMed PMID: 31953624; eng.

44. Stubblefield MD, Keole N. Upper Body Pain and Functional Disorders in Patients With Breast Cancer. PM \& R : the journal of injury, function, and rehabilitation. 2013;6(2):170-83. doi: 10.1016/j.pmrj.2013.08.605. PubMed PMID: 24360839; Eng.

45. Levangie PK, Drouin J. Magnitude of late effects of breast cancer treatments on shoulder function: a systematic review. Breast cancer research and treatment. 2009 Jul;116(1):1-15. doi: 10.1007/s10549-008-0246-4. PubMed PMID: 19031114; eng.

46. De Groef A, Van Kampen M, Vervloesem N, et al. An evaluation tool for myofascial adhesions in patients after breast cancer (MAP-BC evaluation tool): Development and interrater reliability. PloS one. 2017;12(6):e0179116. doi:

10.1371/journal.pone.0179116. PubMed PMID: 28598978.

47. Cantarero-Villanueva I, Fernandez-Lao C, Diaz-Rodriguez L, et al. The handgrip strength test as a measure of function in breast cancer survivors: relationship to cancerrelated symptoms and physical and physiologic parameters. American journal of physical medicine \& rehabilitation / Association of Academic Physiatrists. 2012 Sep;91(9):774-82. doi: 10.1097/PHM.0b013e31825f1538. PubMed PMID: 22760108.

48. De Groef A, Penen F, Dams L, et al. Best-Evidence Rehabilitation for Chronic Pain Part 2: Pain during and after Cancer Treatment. J Clin Med. 2019 Jul 5;8(7). doi: 10.3390/jcm8070979. PubMed PMID: 31284377; PubMed Central PMCID: PMCPMC6678417. eng.

49. Chester R, Jerosch-Herold C, Lewis J, et al. Psychological factors are associated with the outcome of physiotherapy for people with shoulder pain: a multicentre longitudinal cohort study. British journal of sports medicine. 2018 Feb;52(4):269-275. doi: 10.1136/bjsports-2016-096084. PubMed PMID: 27445360; PubMed Central PMCID: PMCPMC5867439. 
Table 1: Overview of the data extracted from the included studies

\begin{tabular}{|c|c|c|c|c|c|c|}
\hline Article & Study population & Treatment & $\begin{array}{l}\text { Dependent } \\
\text { variable (UL } \\
\text { function) }\end{array}$ & $\begin{array}{l}\text { Independent variables } \\
\text { (assessment method) per } \\
\text { category of the ICF model }\end{array}$ & Analyses & $\begin{array}{l}\text { Results (significantly } \\
\text { associated factors from } \\
\text { multivariable analysis) }\end{array}$ \\
\hline \multicolumn{7}{|c|}{ CROSS-SECTIONAL } \\
\hline $\begin{array}{l}\text { Assis et al } 2013 \\
\text { Reference Center of } \\
\text { Women's Health } \\
\text { (Brazil), 2005-2009 }\end{array}$ & $\begin{array}{l}\mathrm{n}=81 \\
\text { - BC stage: NR } \\
\text { - Mean (SD) age: } 52.9(10.12) \mathrm{y} \\
\text { - Mean time since surgery: } \\
1.79 \mathrm{y} \\
\text { Inclusion: } \\
\text { - Female patients } \\
\text { - 1-5 y after surgery } \\
\text { Exclusion: } \\
\text { - Bilateral BC } \\
\text { - Patients with }\end{array}$ & $\begin{array}{l}\text { Surgery: } \\
\text { BCS: } 63 \% \\
\text { ME: } 37 \% \\
\text { SNB: } 18.5 \% \\
\text { ALND: } 81.5 \% \\
\text { Adjuvant } \\
\text { treatment: } \\
\text { chemotherapy: } 16 \% \text {, } \\
\text { radiotherapy: } 10 \%, \\
\text { chemotherapy and } \\
\text { radiotherapy: } 67 \%, \\
\text { hormone therapy or } \\
\text { without }\end{array}$ & DASH & $\begin{array}{l}\text { Function: } \\
\text { - UL } \\
\text { pain (interview) } \\
\text { - Shoulder ROM } \\
\text { (interview) } \\
\text { - Lymphedema } \\
\text { (interview) } \\
\text { - UL numbness } \\
\text { (interview) } \\
\text { Treatment: } \\
\text { (medical record) } \\
\text { - Time since } \\
\text { surgery }\end{array}$ & $\begin{array}{l}\text { Stepwise multivariable } \\
\text { linear regression }\end{array}$ & $\begin{array}{l}\text { - UL Pain (explained } \\
34.7 \% \text { of variance, } \\
p<0.05)^{1} \\
\text { - Length of time since surgery } \\
(p<0.05)^{1} \\
\text { - Limitation in active } \\
\text { shoulder ROM } \\
(p=0.05)^{1} \\
\text { - Lymphedema } \\
(p=0.05)^{1} \\
\text { - UL numbness } \\
(p<0.05)^{1}\end{array}$ \\
\hline
\end{tabular}




\begin{tabular}{|c|c|c|c|c|c|c|}
\hline & $\begin{array}{l}\text { functional } \\
\text { impairment } \\
\text { (motor or sensory) } \\
\text { arising from } \\
\text { sequelae of } \\
\text { diseases or trauma } \\
\text { to the UL prior to surgery }\end{array}$ & $\begin{array}{l}\text { adjuvant } \\
\text { treatment: } 7 \%\end{array}$ & & & & $\begin{array}{l}\rightarrow 53.5 \% \text { of variance in UL } \\
\text { dysfunctions is } \\
\text { explained by pain > length of } \\
\text { time since } \\
\text { surgery > limitation in ROM > } \\
\text { lymphedema }> \\
\text { numbness }\end{array}$ \\
\hline Chrischilles et al 2019 & $\mathrm{n}=833$ & $\begin{array}{l}\text { Surgery: } \\
\text { Unilat ME: } 17 \%\end{array}$ & QuickDASH & $\begin{array}{l}\text { Personal (self-reported): } \\
\text { - Age }\end{array}$ & $\begin{array}{l}\text { Multivariable logistic } \\
\text { regression (Least squares }\end{array}$ & $\begin{array}{l}\text { - combination of } \\
\text { surgery/radiotherapy: patients }\end{array}$ \\
\hline University of Texas & - BC stage: $16 \%$ stage $0,45 \%$ & Bilat ME: 27\% & & - Income & means) (QuickDASH 0 & treated with post-mastectomy \\
\hline Southwestern Medical & stage I, $28 \%$ stage II, $9 \%$ stage & BCS: $56 \%$ & & - BMI at diagnosis & vs $>0$ ) & radiation (accompanied by \\
\hline Center; & III & SNB: $60.6 \%$ & & - Health literacy & & chemotherapy in over $90 \%$ of \\
\hline University of Kansas & - Age: $27.9 \%<50 y, 30.7 \% 50-$ & ALND: $30.5 \%$ & & - Prior rotator cuff/frozen & & cases) experienced the greatest \\
\hline Medical Center; & $59 y, 28.7 \% 60-69 y, 12.7 \%$ & No axillary surgery: & & shoulder & & (9 points) disability compared \\
\hline University of & $>70 y$ & $8.9 \%$ & & - Prior shoulder arthritis & & with the reference category, i.e. \\
\hline Wisconsin & - Mean (SD) time since & & & - Prior diabetes & & unilateral mastectomy \\
\hline Carbone Cancer & diagnosis: 22 (5.4) months & $\underline{\text { Adjuvant }}$ & & & & without radiation (accompanied \\
\hline Center; University of & & treatment: & & Treatment: & & by chemotherapy in $33 \%$ ) \\
\hline Nebraska Medical & Inclusion: & radiotherapy: $65 \%$ & & (self-reported) & & \\
\hline Center; University of & - Female patients & chemotherapy: $46 \%$ & & & & \\
\hline
\end{tabular}




\begin{tabular}{|c|c|c|c|c|c|c|}
\hline $\begin{array}{l}\text { Minnesota; Medical } \\
\text { College } \\
\text { of Wisconsin; and } \\
\text { Marshfield Clinic } \\
\text { Research Foundation } \\
\text { (USA), 2013-2014 }\end{array}$ & $\begin{array}{l}\text { - Ductal carcinoma } \\
\text { in situ or invasive } \\
\text { stage I-III BC } \\
\text { Exclusion: } \\
\text { - Previously } \\
\text { diagnosed with } \\
\text { BC } \\
\text { - Deceased at time } \\
\text { of selection } \\
\text { sample }\end{array}$ & $\begin{array}{l}\text { hormone therapy: } \\
65 \%\end{array}$ & & $\begin{array}{l}\text { - Combination of surgery } \\
\text { and radiotherapy } \\
\text { - Axillary surgery } \\
\text { - Reconstruction } \\
\text { - Hormone therapy }\end{array}$ & & \\
\hline $\begin{array}{l}\text { Dawes et al } 2008 \\
\text { McGill } \\
\text { University Health } \\
\text { Centre, Montreal } \\
\text { (Canada), 1992-2002 } \\
\text { (sub-study of an } \\
\text { epidemiologic study) }\end{array}$ & $\begin{array}{l}\mathrm{n}=50 \\
\text { - BC stage: NR } \\
\text { - Mean (SD) age: } 61(11.8) \mathrm{y} \\
\text { - Mean (SD) time since } \\
\text { diagnosis: } 3.6 \text { (3.1) y } \\
\text { Inclusion: women who had } \\
\text { undergone surgery for unilateral }\end{array}$ & $\begin{array}{l}\text { Surgery: } \\
\text { ME (partial, } \\
\text { segmental, total, } \\
\text { modified, radical) } \\
\text { lumpectomy) } \\
\text { Complementary } \\
\text { treatment: } \\
\text { radiotherapy, }\end{array}$ & DASH & $\begin{array}{l}\text { Function: } \\
\text { - UL } \\
\text { pain (Short Form } \\
\text { McGill pain } \\
\text { questionnaire) } \\
\text { - Arm volume (water } \\
\text { displacement, bioelectrical } \\
\text { impedance, tape } \\
\text { measurement) }\end{array}$ & $\begin{array}{l}\text { Path analyses (regression } \\
\text { coefficients) }\end{array}$ & $\begin{array}{l}\text { Significant paths between UL } \\
\text { dysfunction and: } \\
\text { - number of comorbidities } \\
(\mathrm{r}=4.76, \mathrm{p}<0.05) \\
\text { - UL pain }(\mathrm{r}=0.73, \mathrm{p}<0.05)\end{array}$ \\
\hline
\end{tabular}




\begin{tabular}{|c|c|c|c|c|c|c|}
\hline & $\begin{array}{l}\text { stage I or II BC } \\
\text { Exclusion: not reported }\end{array}$ & $\begin{array}{l}\text { chemotherapy, } \\
\text { ALND, SNB } \\
\text { (Numbers NR) }\end{array}$ & & $\begin{array}{l}\text { - Number of symptoms of } \\
\text { lymphedema (self- } \\
\text { developed questionnaire) } \\
\text { - Number of comorbidities }\end{array}$ & & \\
\hline $\begin{array}{l}\text { Multidisciplinary } \\
\text { Breast Centre of the } \\
\text { University Hospital } \\
\text { Leuven (Belgium), } \\
\text { 2012-2015 }\end{array}$ & $\begin{array}{l}\mathrm{n}=274 \\
\text { - BC stage: 0-III } \\
\text { - Mean (SD) age: } 57.2(10.9) \text { y } \\
\text { - Mean (SD) time after surgery: } \\
1.5 \text { (1.6) y } \\
\text { Inclusion: } \\
\text { - unilateral primary BC } \\
\text { - surgery took } \\
\text { place at least one y ago } \\
\text { Exclusion: } \\
\text { - Current cancer or metastasis }\end{array}$ & $\begin{array}{l}\text { Surgery: } \\
\text { BCS: } 42 \% \\
\text { ME: } 58 \% \\
\text { SNB: } 34 \% \\
\text { ALND: } 66 \% \\
\text { Adjuvant treatment: } \\
\text { radiotherapy: } 89 \% \\
\text { chemotherapy: 50\% } \\
\text { hormone therapy: } \\
79 \% \\
\text { trastuzumab: } 19 \%\end{array}$ & DASH & $\begin{array}{l}\text { Function: } \\
\text { - UL pain intensity (VAS) } \\
\text { - UL pain quality (McGill } \\
\text { pain questionnaire) } \\
\text { - Local pressure } \\
\text { hypersensitivity } \\
\text { (pressure pain thresholds) } \\
\text { - Active shoulder forward } \\
\text { flexion and abduction ROM } \\
\text { (inclinometer), } \\
\text { - Handgrip strength } \\
\text { (handheld } \\
\text { dynamometer) } \\
\text { - Self-reported signs of } \\
\text { central sensitization } \\
\text { (CSI) }\end{array}$ & $\begin{array}{l}\text { 1) multivariable } \\
\text { regression analysis } \\
\text { 2) stepwise regression } \\
\text { analysis }\end{array}$ & $\begin{array}{l}\text { 1) Multivariable regression } \\
\text { analysis: } \\
\text { - active abduction ROM (B=- } \\
0.133,95 \% \mathrm{CI} \text { (-0.232 to - } \\
0.034 \text { ), handgrip } \\
\text { strength (B=-0.310, } 95 \% \mathrm{CI} \text { (- } \\
0.582 \text { to }-0.038) \text {, pain intensity } \\
\text { (B=+0.088, 95\%CI ( } 0.027 \text { to } \\
0.148) \text {, 'total pain rating index' } \\
\text { for pain quality (B=+0.674, } \\
0.232 \text { to } 1.116) \text {, CSI (B= } \\
+0.387,95 \% \mathrm{CI}(0.257 \text { to } 0.516 \text { ) } \\
\text { and } \mathrm{PCS} \text { (B=+0.392, } 95 \% \mathrm{CI} \\
\text { (0.186 to } 0.598 \text { ) } \\
\text { 2) stepwise regression analysis }\end{array}$ \\
\hline
\end{tabular}




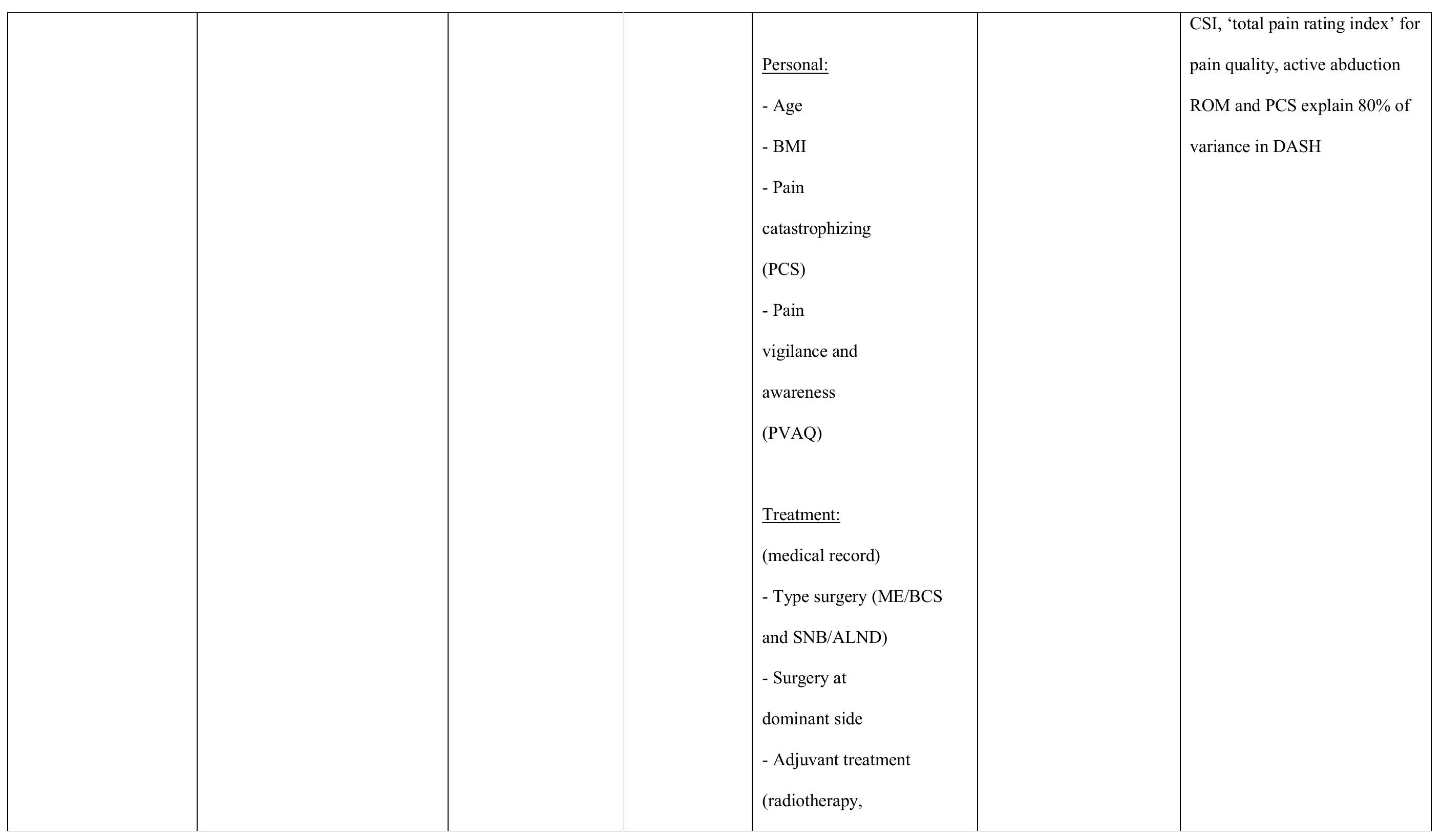




\begin{tabular}{|c|c|c|c|c|c|c|}
\hline & & & & $\begin{array}{l}\text { chemotherapy, trastuzumab, } \\
\text { hormone therapy) }\end{array}$ & & \\
\hline $\begin{array}{l}\text { de Souza Cunha et al } \\
2019 \\
\text { Hospital } \\
\text { Universitário Polydoro } \\
\text { Ernani de São Thiago, } \\
\text { Florianópolis, Santa } \\
\text { Catarina (Brazil), } \\
\text { August } 2016 \text { - April } \\
2017\end{array}$ & $\begin{array}{l}\mathrm{n}=62 \\
\text { - BC stage: NR } \\
\text { - Mean (SD) age: } 51 \text { (8.18) y } \\
\text { - Mean (SD) time since } \\
\text { diagnosis: NR } \\
\text { Inclusion: } \\
\text { - age 30-65 y } \\
\text { - adjuvant therapies } \\
\text { (chemotherapy and/or } \\
\text { radiotherapy) finished in prior } 3 \\
\text { months } \\
\text { - working population (before } \\
\text { diagnosis) } \\
\text { Exclusion } \\
\text { - psychiatric/psychology disease }\end{array}$ & $\begin{array}{l}\text { Surgery: } \\
\text { ME: } 43(69.4 \%) \\
\text { ALND: } 45(72.6 \%) \\
\text { SNB: } 13(21.0 \%) \\
\text { Adjuvant treatment: } \\
\text { chemotherapy: } 48 \\
\text { (77.40\%) } \\
\text { radiotherapy: } 43 \\
\text { (69.40\%) } \\
\text { hormone therapy: } 48 \\
\text { (77.40\%) }\end{array}$ & DASH & $\begin{array}{l}\text { Function: } \\
\text { - Pain in upper quadrant at } \\
\text { affected side (VAS) } \\
\text { - Weakness in arms (self- } \\
\text { reported 0-100) } \\
\text { - Stiffness in shoulder (self- } \\
\text { reported 0-100) }\end{array}$ & $\begin{array}{l}\text { Multivariable linear } \\
\text { regression }\end{array}$ & $\begin{array}{l}\text { - pain in upper quadrant at } \\
\text { affected side ( } \mathrm{B}=0.8 ; \mathrm{p}=0.001) \\
64 \% \text { of variance in the DASH- } \\
\text { scores is explained by pain in } \\
\text { upper quadrant at affected side }\end{array}$ \\
\hline
\end{tabular}




\begin{tabular}{|c|c|c|c|c|c|c|}
\hline & $\begin{array}{l}\text { - rheumatological/chronic } \\
\text { musculoskeletal disease } \\
\text { - cancer recurrence } \\
\text { - palliative care }\end{array}$ & & & & & \\
\hline $\begin{array}{l}\text { Hack et al } 2010 \\
\text { Cancer clinics in } \\
\text { Montreal, Surrey, } \\
\text { Winnipeg and } \\
\text { Fredericton (Canada), } \\
\text { dates not reported }\end{array}$ & $\begin{array}{l}\mathrm{n}=316 \\
\text { - BC stage: } 39.2 \% \text { stage I, } \\
44.3 \% \text { stage II, } 16.5 \% \text { stage III } \\
\text { - Mean (SD) age: } 54.3 \text { (11.0) y } \\
\text { - Mean time since surgery: } \\
253.9 \text { days } \\
\text { Inclusion: } \\
\text { - Women (>18y) } \\
\text { - stage I-III unilateral breast } \\
\text { cancer with BCS or ME } \\
\text { - Time since surgery 6-12 } \\
\text { months } \\
\text { Exclusion: }\end{array}$ & $\begin{array}{l}\text { Surgery: } \\
\text { BCS: } 74.7 \% \\
\text { ME: } 25.3 \% \\
\text { SNB: } 22.2 \% \\
\text { ALND: } 78.0 \% \\
\text { Adjuvant treatments: } \\
\text { radiotherapy: } 94.6 \% \\
\text { chemotherapy: } 70.3 \%\end{array}$ & DASH & $\begin{array}{l}\text { Personal: } \\
\text { - BMI } \\
\text { - Education level } \\
\text { External: } \\
\text { - Partner status } \\
\text { Treatment: } \\
\text { (medical record) } \\
\text { - SNB/ALND } \\
\text { - ME/BCS } \\
\text { - Number of axillary } \\
\text { nodes dissected } \\
\text { - Disease stage } \\
\text { - Post-operative }\end{array}$ & $\begin{array}{l}\text { Multivariable regression } \\
\text { analyses }\end{array}$ & $\begin{array}{l}\text { - BMI }(p=0.026) \\
\text { - Post-op infections } \\
(p=0.036)\end{array}$ \\
\hline
\end{tabular}




\begin{tabular}{|c|c|c|c|c|c|c|}
\hline & $\begin{array}{l}\text { - Metastatic, bilateral, in-situ } \\
\text { and/or recurrent BC }\end{array}$ & & & $\begin{array}{l}\text { infection } \\
\text { - Radiotherapy to the axilla } \\
\text { - Time since surgery }\end{array}$ & & \\
\hline $\begin{array}{l}\text { Harrington et al } 2013 \\
\text { The BCS group } \\
\text { was recruited through } \\
\text { physicians who had } \\
\text { knowledge } \\
\text { of the Get REAL and } \\
\text { HEEL Breast Cancer } \\
\text { Research } \\
\text { Program eligibility } \\
\text { criteria at the } \\
\text { University of North } \\
\text { Carolina-Chapel Hill } \\
\text { (UNC-CH), dates not } \\
\text { specified }\end{array}$ & $\begin{array}{l}\mathrm{n}=24 \\
\text { - BC stage: 0-III (numbers NR) } \\
\text { - Mean (SD) age: } 50.8(9.5) \mathrm{y} \\
\text { - Mean time since surgery: NR } \\
\text { Inclusion: } \\
\text { - Finished surgery, radiotherapy } \\
\text { and chemotherapy } \leq 6 \text { months } \\
\text { before inclusion } \\
\text { - Female } 25-75 \text { y } \\
\text { - No recent history (6 months } \\
\text { before diagnosis of BC) of } \\
\text { rehabilitation for UL, thoracic } \\
\text { or cervical condition } \\
\text { - No known neuromuscular } \\
\text { dysfunctions or taking }\end{array}$ & $\begin{array}{l}\text { Surgery: } \\
\text { BCS: } 33 \% \\
\text { ME: } 67 \% \\
\text { Adjuvant treatments: } \\
\text { radiotherapy: } 88 \% \\
\text { chemotherapy: } 79 \%\end{array}$ & $\begin{array}{l}\text { 1) DASH } \\
\text { 2) PSS }\end{array}$ & $\begin{array}{l}\text { Function: } \\
\text { - Shoulder active } \\
\text { ROM (inclinometer) } \\
\text { - Shoulder passive ROM } \\
\text { (inclinometer) } \\
\text { - Shoulder girdle } \\
\text { strength (hand-held } \\
\text { dynamometer) }\end{array}$ & $\begin{array}{l}\text { Forward stepwise } \\
\text { multivariable regression } \\
\text { analyses }\end{array}$ & $\begin{array}{l}\text { 1) } \underline{\mathrm{DASH}} \\
\text { - Active ROM accounted for } \\
40 \% \text { variance, } \mathrm{r}=-0.63, \mathrm{p}= \\
0.001 \\
\text { 2) } \underline{\mathrm{PSS}} \\
\text { - Shoulder girdle } \\
\text { strength accounted for } 20 \% \\
\text { variance, } \mathrm{r}=0.45, \mathrm{p}=0.02\end{array}$ \\
\hline
\end{tabular}




\begin{tabular}{|c|c|c|c|c|c|c|}
\hline & $\begin{array}{l}\text { medications that may have an } \\
\text { influence on neuromuscular } \\
\text { performance }\end{array}$ & & & & & \\
\hline $\begin{array}{l}\text { Hayes et al } 2005 \\
\text { Brisbane, Queensland } \\
\text { (Australia), } 2002\end{array}$ & $\begin{array}{l}\mathrm{n}=258 \\
\text { - BC stage: stage I } 26.5 \% \text {, stage } \\
\text { II } 31.4 \% \text {, stage III } 32.2 \% \\
\text { - Mean (SD) age: } 53 \text { (10) y } \\
\text { - Time after surgery: } 6 \text { months } \\
\text { Inclusion: } \\
\text { - Women with unilateral BC } \\
\text { - Aged } \leq 75 \text { y } \\
\text { - Within } 100 \text { km of Brisbane }\end{array}$ & $\begin{array}{l}\text { Surgery: } \\
\text { BCS: } 72.2 \% \\
\text { ME: } 27.8 \% \\
\text { ALND: } 86.8 \% \\
\text { SNB: } 13.4 \% \\
\text { Adjuvant treatment: } \\
\text { radiotherapy: } 71 \% \\
\text { chemotherapy: } 44 \% \\
\text { hormone therapy: } \\
42 \%\end{array}$ & DASH & $\begin{array}{l}\text { All self-reported } \\
\text { Function: } \\
\text { - Diagnosis of } \\
\text { lymphedema } \\
\text { Personal: } \\
\text { - Age } \\
\text { - BMI } \\
\text { - Income } \\
\text { - Occupation } \\
\text { - Level of education } \\
\text { External: } \\
\text { - Marital status } \\
\text { - Number and age of } \\
\text { children }\end{array}$ & $\begin{array}{l}\text { Multivariable linear } \\
\text { regression model }\end{array}$ & - Income $(\mathrm{p}<0.001)$ \\
\hline
\end{tabular}




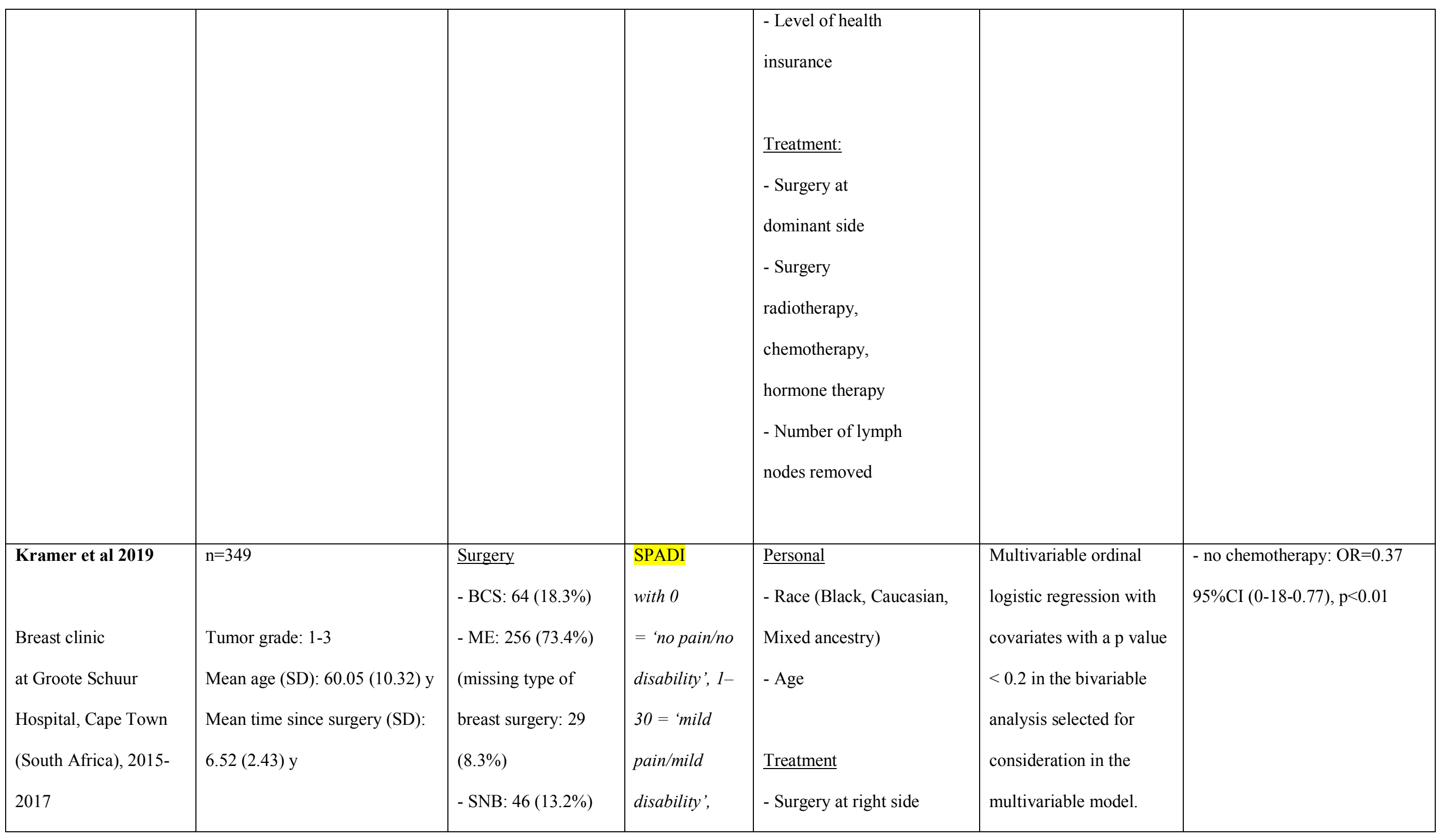




\begin{tabular}{|c|c|c|c|c|c|c|}
\hline & $\begin{array}{l}\text { Inclusion criteria: } \\
\text { - unilateral BC } \\
\text { - Women } 18 \text { y of age and older } \\
\text { - } \geq 1 \text { y post-surgery } \\
\text { Exclusion criteria } \\
\text { - Reconstructive surgery } \\
\text { - Current or previous history of } \\
\text { shoulder complex trauma, } \\
\text { surgery, pathology or } \\
\text { dysfunction } \\
\text { - Current or previous history of } \\
\text { cervical neuropathy }\end{array}$ & $\begin{array}{l}\text { - ALND: } 273 \\
(78.2 \%) \\
\text { (missing type of } \\
\text { axillary surgery: } 30 \\
(8.6 \%)) \\
\text { Adjuvant treatment } \\
\text { chemotherapy: } 254 \\
\text { (72.8\%) } \\
\text { radiotherapy: } 221 \\
\text { (63.3\%) } \\
\text { hormonal therapy: } \\
246 \text { (70.5\%) }\end{array}$ & $\begin{array}{l}31-50= \\
\text { 'moderate } \\
\text { pain/moderate } \\
\text { disability' and } \\
>50=\text { 'severe } \\
\text { pain/severe } \\
\text { disability' }\end{array}$ & $\begin{array}{l}\text { - Tumor grade (1-3) } \\
\text { - Number of lymph nodes } \\
\text { dissected } \\
\text { - No chemotherapy } \\
\text { - No hormonal therapy } \\
\text { - Date of surgery } \\
\text { - Radiotherapy } \\
\text { - Type of breast surgery } \\
\text { (BCS/ME) } \\
\text { - Type of axillary surgery } \\
\text { (SNB/ALND) }\end{array}$ & & \\
\hline $\begin{array}{l}\text { Marazzi et al } 2019 \\
\text { Setting not reported, } \\
2016\end{array}$ & $\begin{array}{l}\mathrm{n}=111 \\
\text { - BC stage: } 8 \% \text { stage } 0,56.7 \% \\
\text { stage } 1,18.9 \% \text { stage II, } 15.4 \% \\
\text { stage III, } 1 \% \text { stage IV }\end{array}$ & $\begin{array}{l}\text { Surgery: } \\
\text { BCS: } 93 \% \\
\text { ME: } 6 \% \\
\text { excisional biopsy: } \\
1 \% \\
\text { ALND: } 40 \%\end{array}$ & DASH & $\begin{array}{l}\text { Function: } \\
\text { - Lymphedema } \\
\text { (circumference } \\
\text { measurement) } \\
\text { - Active shoulder ROM } \\
\text { (goniometer) }\end{array}$ & $\begin{array}{l}\text { Cox linear regression } \\
\text { analyses }\end{array}$ & $\begin{array}{l}\text { - Active shoulder } \\
\text { ROM abduction } \\
(\mathrm{p}<0.0001)\end{array}$ \\
\hline
\end{tabular}




\begin{tabular}{|c|c|c|c|c|c|c|}
\hline & $\begin{array}{l}\text { - Mean (range) age: } 60 \text { (41-85) } \\
\text { y } \\
\text { - Mean (range) time since } \\
\text { radiotherapy: } 34 \text { (6-66) months } \\
\text { Inclusion: } \\
\text { - Women after BC surgery } \\
\text { - Adjuvant radiotherapy with or } \\
\text { without chemotherapy and/or } \\
\text { hormone treatment } \\
\text { - Absence of moderate/severe } \\
\text { arthrosis history and/or } \\
\text { rheumatologic diseases } \\
\text { - At least } 6 \text { months follow-up } \\
\text { from the end of radiotherapy } \\
\text { - Absence of locoregional or } \\
\text { distant relapse }\end{array}$ & $\begin{array}{l}\text { SNB: } 59 \% \\
\text { no axillary surgery: } \\
1 \% \\
\text { Adjuvant } \\
\text { Treatment: } \\
\text { radiotherapy: } 100 \% \\
\text { chemotherapy: } 3 \%\end{array}$ & & $\begin{array}{l}\text { - Pain (VAS) } \\
\text { Personal: } \\
\text { - Age } \\
\text { - Occupation } \\
\text { Treatment: } \\
\text { (medical record) } \\
\text { - Stage of BC at } \\
\text { diagnosis } \\
\text { - Type of surgery on } \\
\text { breast and axilla } \\
\text { - Radiotherapy } \\
\text { (doses and } \\
\text { volumes), } \\
\text { chemotherapy } \\
\text { and/or hormonal } \\
\text { therapy }\end{array}$ & & \\
\hline Smoot et al 2010 & $\mathrm{n}=144$ & $\begin{array}{l}\text { Surgery: } \\
\text { BCS: } 57 \%\end{array}$ & DASH & $\begin{array}{l}\text { Function: } \\
\text { - Lymphedema }\end{array}$ & $\begin{array}{l}\text { Multivariable linear } \\
\text { regression }\end{array}$ & $\begin{array}{l}\text { - Past diagnosis of } \\
\text { lymphoedema }\end{array}$ \\
\hline
\end{tabular}




\begin{tabular}{|c|c|c|c|c|}
\hline National Lymphedema & - BC stage: 0-III & ME: $43 \%$ & (diagnosis based on & $(\mathrm{p}<.0 .001)$ \\
\hline Network website, & - Mean (SD) age: 56.33 (9.44) y & ALND: $75 \%$ & circumference and & - Grip strength \\
\hline San Francisco Bay area & - Mean (SD) time since & SNB: $25 \%$ & bioimpedance) & $(\mathrm{p}<0.001)$ \\
\hline hospitals, San & diagnosis: 6.17 (5.35) y & & - UL strength (handheld & - Shoulder abduction \\
\hline Francisco Bay area & & $\underline{\text { Adjuvant treatment: }}$ & dynamometer) & $\operatorname{ROM}(\mathrm{p}=0.003)$ \\
\hline breast cancer or & Inclusion: & radiotherapy: $74 \%$ & - Grip strength (full grip - & - Number of \\
\hline lymphedema support & - Unilateral BC & chemotherapy: $70 \%$ & hand dynamometer, key grip & comorbidities \\
\hline groups, and breast & - With/without lymphedema & & pinch gauge, pinch grip - & $(p<0.001)$ \\
\hline cancer conferences, & - Completed BC treatment 6 & & microfet2) & \\
\hline \multirow[t]{11}{*}{ dates not reported. } & months prior to assessment & & - Fine motor skills & $46.3 \%$ of the variance in \\
\hline & - Read, speak, and understand & & (Purdue Pegboard & the DASH-scores is explained \\
\hline & English & & \& Finger Tapper & by these four variables. \\
\hline & & & Test) & \\
\hline & Exclusion: & & - shoulder ROM & \\
\hline & - Bilateral BC & & (goniometer) & \\
\hline & - Current UL infection & & - Tactile sensitivity & \\
\hline & - Lymphangitis & & (monofilaments) & \\
\hline & - Pre-existing lymphedema & & - Vibration & \\
\hline & & & perception & \\
\hline & & & threshold & \\
\hline
\end{tabular}




\begin{tabular}{|c|c|c|c|c|c|c|}
\hline & $\begin{array}{l}\text { - Pre-existing neuromuscular or } \\
\text { musculoskeletal conditions of } \\
\text { the UL } \\
\text { - Recurrence of BC }\end{array}$ & & & $\begin{array}{l}\text { (biothesiometer) } \\
\text { - Menopausal status } \\
\text { Personal: } \\
\text { (demographic questionnaire) } \\
\text { - Comorbidities } \\
\text { - Age } \\
\text { - Ethnicity } \\
\text { - Performance and activity } \\
\text { status } \\
\text { - Income } \\
\text { - Occupation }\end{array}$ & & \\
\hline \multicolumn{7}{|l|}{ LONGITUDINAL } \\
\hline $\begin{array}{l}\text { Hayes et al } 2008 \\
\text { Institute of Health and } \\
\text { Biomedical Innovation, } \\
\text { School of Public } \\
\text { Health; and School of } \\
\text { Physical and }\end{array}$ & $\begin{array}{l}\mathrm{n}=246 \\
\text { Stage: } 26.6 \% \text { stage I, } 31.8 \% \\
\text { stage II, } 30.6 \% \text { stage III, } 11.5 \% \\
\text { stage unavailable } \\
\text { Mean (SD) age: } 55 \text { (10) y } \\
\text { Time since surgery: NR }\end{array}$ & $\begin{array}{l}\text { Surgery: } \\
\text { - BCS: } 72.5 \% \\
\text { - ME: } 27.5 \% \\
\text { - SNB: } 13.3 \% \\
\text { - ALND: } 86.7 \% \\
\text { Adjuvant treatment }\end{array}$ & $\begin{array}{l}18 \text { months } \\
\text { after surgery } \\
\text { DASH } \\
\text { (dichotomized } \\
\text { as worse than } \\
\text { most versus }\end{array}$ & $\begin{array}{l}\text { Every three months between } \\
6 \text { and } 18 \text { months after } \\
\text { surgery } \\
\underline{\text { Function }}\end{array}$ & $\begin{array}{l}\text { Multivariable logistic } \\
\text { regression analysis }\end{array}$ & $\begin{array}{l}\text { Factors associated with having } \\
\text { poorer upper body function at } \\
18 \text { months: } \\
\text { - Having lymphedema at } 6 \text { and } \\
18 \text { months post } \\
\text { surgery/diagnosis (OR=1.9; } \\
95 \% \text { CI ( } 0.8 \text { to } 4.6) ; \mathrm{P}=0.15) \text {; }\end{array}$ \\
\hline
\end{tabular}




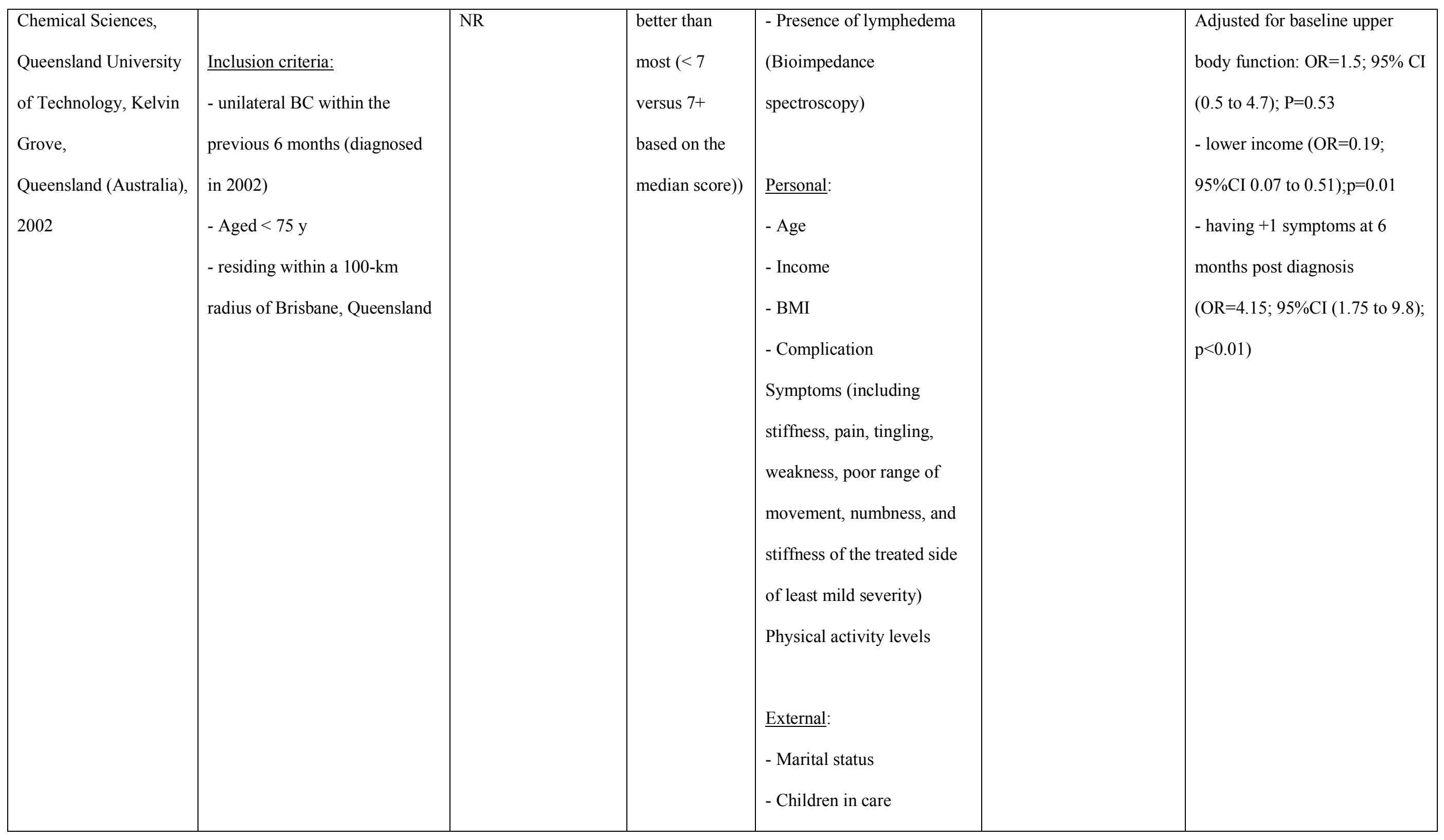




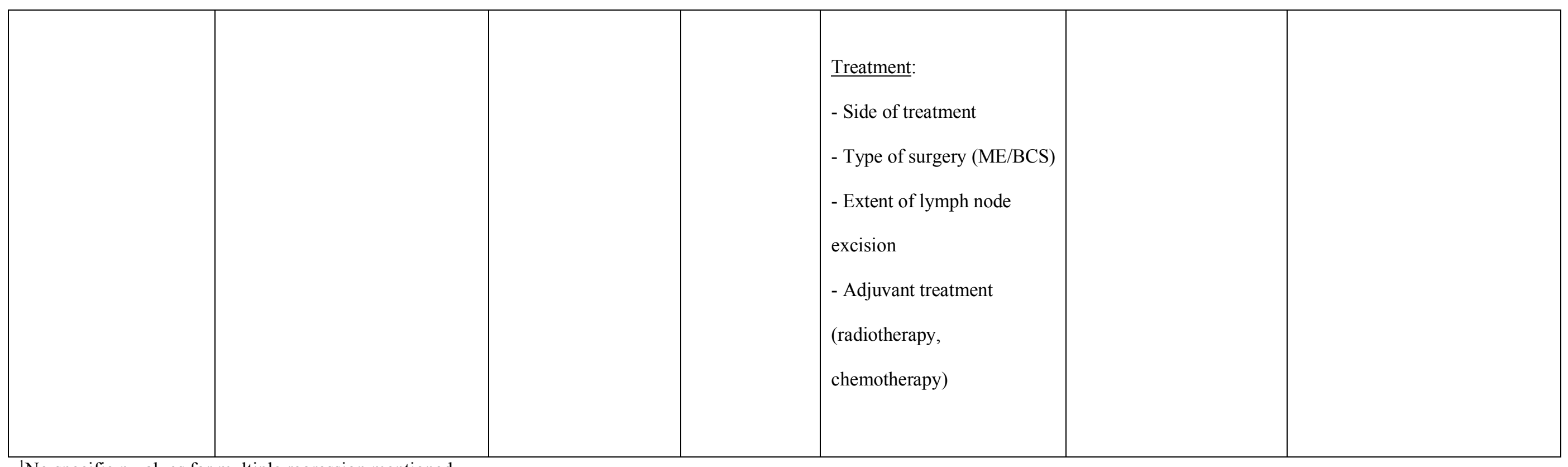

${ }^{1}$ No specific $\mathrm{p}$-values for multiple regression mentioned

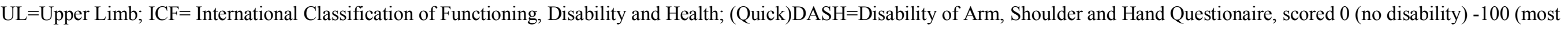

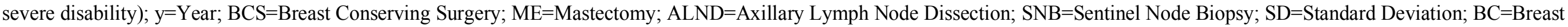

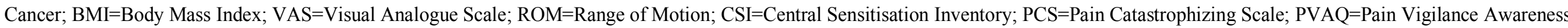

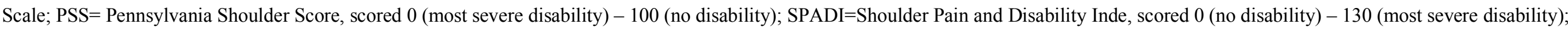
$\mathrm{NR}=$ Not Reported 
Table 2. Summary of variables with or without association with upper limb function per category of the International Classification of Functioning, Disability and Health. Author (year) and assessment method of the variables with and without association with upper limb function are listed.

Associated factors

\section{Assessed independent factors}

Upper limb pain intensity

Upper limb pain quality

Shoulder active range of motion

Assis 2013 - Interview

De Groef 2017 - VAS

de Souza Counha 2019 - VAS

Factors without association

\section{FUNCTION}

Marazzi $2019-\mathrm{VAS}$

Dawes 2008 - McGill pain Questionnaire

De Groef 2017 - McGill pain Questionnaire

Assis 2013 - Interview

De Groef 2017 - Abduction - Inclinometer

Harrington 2013 - Inclinometer (Outcome DASH)

Marazzi 2019 - abduction - Goniometer

Smoot 2010 - abduction - Goniometer
De Groef 2017 - Forward flexion - Inclinometer

Harrington 2013 - Inclinometer (Outcome PSS)

Marazzi 2019 - forward flexion and rotations - Goniometer

Smoot 2010 - forward flexion and rotations - Goniometer

de Souza Cunha 2019 (self-reported)
Shoulder passive range of motion

Lymphedema/arm swelling

\section{Assis 2013 - Interview}

Smoot 2010 - past diagnosis - self-reported

Hayes 2008 - BIS
Harrington 2013 - Inclinometer (outcome DASH and PSS)

Dawes 2008 - Number of symptoms of lymphedema - self-developed questionnaire and

water displacement, bioelectrical Impedance, tape measurement

Hayes 2005 - presence of lymphoedema - self-reported

Marazzi 2019 - circumference measurement 


\section{Smoot 2010 - self-reported}

\section{Local pressure hypersensitivity}

Shoulder girdle/upper limb strength

Harrington 2013 - Hand-held dynamometer (Outcome PSS)
De Groef 2017 - pressure pain thresholds with algometer

Harrington 2013 - Hand-held Dynamometer (Outcome DASH)

Smoot 2010 - shoulder abduction, elbow flexion and wrist flexion- handheld

$$
\text { Dynamometer }
$$

de Souza Cunha 2019 (self-reported)
De Groef 2017 - handheld

$$
\text { Dynamometer }
$$

Smoot 2010 - full handgrip with hand

dynamometer/key grip with pinch gauge/pinch grip with microfet2

\section{Fine motor skills}

Tactile sensitivity

Vibration perception threshold

Signs of central sensitization

Menopausal status

$>1$ Symptom ((include stiffness, pain, tingling,

weakness, poor range of movement,

numbness, and stiffness of the treated side of

least mild severity)

\section{TREATMENT}

Time since surgery

Assis 2013 - Medical record

\section{Smoot 2010 - Purdue Pegboard \& Finger Tapper Test}

Smoot $2010-$ monofilament

Smoot 2010 - Biothesiometer

\section{De Groef 2017 - Central Sensitization Inventory}

Smoot 2010 - self-reported

Hack 2010 - medical record

Kramer 2019 - medical record 
Kramer 2019 - Tumour grade/number of lymph nodes dissected - medical record

Post-operative infection

Type of surgery (SNB/ALND and ME/BCS)

Hack 2010 - medical record

Surgery on dominant side

Surgery at right side

Adjuvant treatment
Kramer 2019- no chemotherapy - medical record

Chrischilles 2019 - combination surgery and radiotherapy - self-reported
De Groef 2017 - medical record

Hack 2010 - medical record

Hayes 2005 - self-reported

Marazzi 2019 - medical record

Hayes 2008 - self-report

Kramer 2019 - medical record

De Groef 2017 - medical record

Hayes 2005 - self-reported

Hayes 2008 - self-report
Kramer 2019 - medical record

Chrischilles - axillary surgery/reconstruction/hormone therapy - self-reported

De Groef 2017 - radiotherapy/chemotherapy/trastuzumab/hormone therapy - medical

record

Hack 2010 - radiotherapy to axilla - medical record

Hayes 2005 - radiotherapy/chemotherapy/hormone therapy - self-reported

Hayes 2008 - chemotherapy/radiotherapy - self-report

Marazzi 2019 - radiotherapy/chemotherapy/endocrinal therapy - medical record

Kramer 2019 - chemotherapy/no hormone therapy/radiotherapy - medical record

Chrischilles $2019-$ self-reported 
De Groef 2017 - self-reported

Hayes 2005 - self-reported

Marazzi 2019 - self-reported

Smoot 2010 - self-reported

Hayes 2008 - self-reported

Kramer 2019 - self-reported

Smoot $2010-$ self-reported

Kramer 2019 - self-reported

Hayes 2005 - self-reported

Marazzi 2019 - self-reported

Smoot 2010 - self-reported

\section{Education level}

Hack 2010 - self-reported)

Hayes 2005 - self-reported Smoot 2010 - self-reported

Income

Hayes 2005 - self-reported

Hayes 2008 - self-reported

BMI
Hack 2010 - clinical assessment

Chrischilles 2019 - self-reported

Chrischilles 2019 - self-reported

De Groef 2017 - clinical assessment

Hayes 2005 - self-reported

Hayes 2008 - self-reported Chrischilles 2019-self-reported Smoot 2010 - self-reported

Hayes 2008 - self-report

Chrischilles 2019- self-reported

Chrischilles 2019-self-reported

Prior shoulder complaints

Pain catastrophizing
De Groef 2017 - Pain Catastrophizing Scale 
EXTERNAL

Chrischilles 2019 - self-reported

\section{Partner status}

Hack 2010 - self-reported

Hayes 2005 - self-reported

Hayes 2008 - self-reported Hayes 2005 - self-reported

Insurance state

Hayes $2005-$ self-reported

Hayes 2008 - self-reported

VAS: Visual Analogue Scale; ND=not defined; BC=Breast Cancer; DASH=Disability of Arm, Shoulder and Hand questionnaire; PSS=Pennsylvania Shoulder Score; BIS=Bioimpedance

Score 
Table 3. Risk of bias according to the QUIPS tool.

\begin{tabular}{|c|c|c|c|c|c|c|c|}
\hline & $\begin{array}{l}\text { 1. Study } \\
\text { Participation }\end{array}$ & 2. Study Attrition & $\begin{array}{l}\text { 3. Prognostic Factor } \\
\text { Measurement }\end{array}$ & $\begin{array}{l}\text { 4. Outcome } \\
\text { Measurement }\end{array}$ & 5. Study Confounding & $\begin{array}{l}\text { 6. Statistical Analysis } \\
\text { and Reporting }\end{array}$ & Overall risk \\
\hline Assis et al, 2013 & Low risk & Low risk & High risk & Low risk & High risk & Moderate risk & Moderate \\
\hline Chrischilles et al, 2019 & Low risk & Low risk & High risk & Low risk & Moderate risk & Low risk & Low \\
\hline Dawes et al, 2008 & Moderate risk & Moderate risk & Moderate risk & Low risk & Moderate risk & Low risk & Moderate \\
\hline De Groef et al, 2017 & Moderate risk & Moderate risk & Low risk & Low risk & Low risk & Low risk & Low \\
\hline de Souza Cunha et al, 2019 & Moderate risk & Moderate risk & High risk & Low risk & Moderate risk & Low risk & Moderate \\
\hline Hack et al, 2010 & Low risk & Low risk & Low risk & Low risk & Moderate risk & Low risk & Low \\
\hline Harrington et al., 2013 & Moderate risk & Moderate risk & Moderate risk & Low risk & Moderate risk & Moderate risk & Moderate \\
\hline Hayes et al., 2005 & Moderate risk & Moderate risk & High risk & Low risk & Low risk & Moderate risk & Moderate \\
\hline Hayes et al., 2008 & Moderate risk & Moderate risk & High risk & Low risk & Low risk & Moderate risk & Moderate \\
\hline Kramer et al, 2019 & Low risk & Moderate risk & Low risk & Low risk & Moderate risk & Moderate risk & Low \\
\hline Marazzi et al, 2019 & Moderate risk & Moderate risk & Low risk & Low risk & Moderate risk & Moderate risk & Moderate \\
\hline Smoot et al., 2010 & Moderate risk & Moderate risk & Low risk & Low risk & Low risk & Low risk & Low \\
\hline
\end{tabular}

QUIPS tool: Quality In Prognosis Studies tool 
Table 1. Table 1: Overview of the data extracted from the included studies

Table 2. Summary of variables with or without association with upper limb function per category of the International Classification of Functioning, Disability and Health. Author (year) and assessment method of the variables with and without association with upper limb function are listed.

Table 3. Risk of bias according to the QUIPS tool.

Figure 1. Flowchart visualizing the selection process 